\title{
Positive psychology leadership coaching experiences in a financial organisation
}

\author{
Author: \\ Frans Cilliers ${ }^{1}$ \\ Affiliation: \\ ${ }^{1}$ Department of Industrial \\ and Organisational \\ Psychology, University of \\ South Africa, Pretoria, \\ South Africa \\ Correspondence to: \\ Frans Cilliers \\ Email: \\ cillifvn@unisa.ac.za \\ Postal address: \\ PO Box 392, UNISA 0003, \\ South Africa \\ Dates: \\ Received: 31 Aug. 2010 \\ Accepted: 08 July 2011 \\ Published: 27 Oct. 2011 \\ How to cite this article: \\ Cilliers, F. (2011). Positive \\ psychology leadership \\ coaching experiences in \\ a financial organisation. \\ SA Journal of Industrial \\ Psychology/SA Tydskrif vir \\ Bedryfsielkunde, 37(1), Art. \\ \#933, 14 pages. http:// \\ dx.doi.org/10.4102/sajip. \\ v37i1.933
}

Orientation: Organisations are practising leadership coaching more and more from a positive psychology perspective, yielding positive results. The current qualitative research focused on this coaching using work engagement, learned resourcefulness, sense of coherence, selfactualisation and locus of control as constructs. Although the researcher could find no previous research on this combination of constructs, the findings did link to previous studies with other constructs and combinations.

Research purpose: The purpose of this research was to describe the positive psychology leadership coaching experiences of leaders in a large financial organisation.

Motivation for the study: The researcher addressed the organisation's need to develop leadership by structuring and presenting a coaching programme. He chose positive psychology as the paradigm and experiential learning as the method to meet the organisation's goal of enabling its leaders to take up their roles with self-awareness, internal motivation and effective interpersonal connections.

Research design, approach and method: The researcher used a qualitative and descriptive research design with a case study. Leaders attended ten experiential leadership-coaching sessions over three months. The sessions focused on work engagement, learned resourcefulness, sense of coherence, self-actualisation values and locus of control. The data gathering consisted of the coach's field notes and the participants' reflective essays, which they wrote after the last coaching session. The researcher analysed the data using discourse analysis.

Main findings: The manifesting themes were the coaching context, engagement in roles, understanding role complexity, emotional self-awareness and demands, self-authorisation and inability to facilitate the growth of others.

Contribution/value-add: Although intrapersonal awareness increased significantly, leaders struggled with the interpersonal complexity of the leadership role. Positive psychology leadership coaching should refine the operationalisation of interpersonal effectiveness.

Practical/managerial implications: Organisations should integrate the methodology of leadership coaching with leadership development interventions to expose leaders to better intrapersonal awareness and functioning.

\section{Introduction}

The fast development and practice of, as well as research in, positive psychology coaching have resulted in a substantial body of knowledge. The literature reports on this coaching, which involves many positive psychology constructs. However, the researcher could find no research that studies the effect of positive psychology leadership coaching, set in a leadership development programme, which specifically covers work engagement, resourcefulness, sense of coherence, self-actualisation values and locus of control. This research addresses this matter qualitatively.

Positive psychology, as a paradigm and theory, has proved successful in developing people skills (Jonker, 2009; Linley \& Joseph, 2004; Sheldon, Kashdan \& Steger, 2011; Sheldon \& King, 2001). It includes methods like psychotherapy, coaching, developmental programmes, training and Internet-based interventions (Kauffman, 2006; Seligman, Steen, Park \& Peterson, 2005).

Organisations have used positive psychology coaching to improve functioning in various constructs (Biswas-Diener, 2010; De Haan \& Burger, 2004; Kauffman, 2006; Peterson, 1996; Robson, 2011); examples are: 
- respect and empathy (Stout Rostron, 2009)

- happiness (Biswas-Diener \& Dean, 2007; Buss, 2000; Lyubomirsky, 2001; Seligman, Steen, Park \& Peterson, 2005)

- positive character strengths (Biswas-Diener \& Dean, 2007; Linley \& Harrington, 2006; Linley, Woolston \& BiswasDiener, 2009)

- emotional intelligence (Cherniss, 2010; Goleman, Boyatzis \& McKee, 2008; Wall, 2007)

- hardiness and resilience (Maddi \& Khoshaba, 2005)

- curiosity (Kashdan, 2009)

- hope (Peterson \& Luthans, 2003).

Positive psychology coaching also improved management effectiveness and self-efficacy beliefs (Evers, Brouwers \& Tomic, 2006) as well as productivity (Olivero, Bane \& Kopelman, 1997).

On the other hand, the literature warns that positive psychology coaching has limitations. It seems that, although positive psychology applications are moving ahead quickly and furiously, its interventions may be outpacing the science (Azar, 2011). As evidence, she mentioned that popular culture, self-help gurus, life and 'happiness' coaches and many so-called resiliency training courses have dominated the field. Furthermore, these interventions seldom receive scientific assessments.

Nelson and Hogan (2009) refer to 'coaching on the dark side', reminding the coaching fraternity that the positive psychology lens may not always be appropriate. Their argument was that a client's dysfunctional personality dispositions and interpersonal strategies might prevent relationships between the coach and the client from forming. They may also hinder personal and interpersonal learning and growth during coaching.

Although this literature applies to positive psychology leadership coaching, its content is not set specifically in the leadership domain. Modern leaders, who are not able to rely only on position and authority, are acknowledged (Biswas-Diener \& Dean, 2007; Wall, 2007). This suggests that high levels of positive psychology functioning are necessary. Unfortunately, the literature does not link positive psychology functioning to specific leadership behaviours.

The researcher could find only a limited number of leadership coaching studies that show that they have improved positive psychology constructs. Greif (2007) reported on leaders' cognitive functioning, Grant (2003) on improving selfreflection, Grant (2007) on flourishing, and Finn, Mason and Griffin (2006) on self-efficacy, positive affect and openness to new behaviours. Although these studies gave some direction about effective positive psychology leadership coaching, their limitations included a lack of generalisation to other coaching scenarios. The researcher could find no in-depth qualitative studies that investigated changes in positive psychology functioning as part of leadership coaching.

\section{Positive psychology leadership coaching}

With regard to task leadership, as opposed to people leadership (Blake \& McCanse, 1995), the coaching literature provides convincing evidence about its contribution to a significant return on investment (McGovern, Lindemann, Vergara, Murohy, Barker \& Warrenfeltz, 2001) and on achieving the goals of organisations (McKenna \& Davis, 2009).

Organisational psychology references tend to focus on coaching from a mechanistic perspective and report results on cognitive learning about leadership (Coutu \& Kaufman, 2009; Goldsmith, Lyons \& Freas, 2000; Harvard Business Essentials, 2004).

Research from a systems psychodynamic paradigm (Brunning, 2006; Chapman \& Cilliers, 2008; Cilliers \& Terblanche, 2010) reports on leaders' raised awareness in their relationships with, and relatedness to, the systems of organisations. However, this falls outside of the scope of this study.

The literature generally defines leadership as activities that involve, influence, coordinate and guide people's organisational activities willingly towards achieving positive goals and outcomes for organisations using strategies, challenges and goals (Avolio, 2007; Bennis, 2007; Kaiser, Hogan \& Craig, 2008; Nohria \& Khurana, 2010).

It defines leadership coaching as regular, short-term and highly focused organisational learning opportunities as opposed to therapy and traditional training (Grant, 2007). It involves facilitating relationships between clients, who have managerial authority and responsibility in their organisations, and consultants who use behavioural techniques and methods to help clients improve their personal insights and to realise effective leadership performance. Its outcomes are to improve the effectiveness of organisations within the boundaries of formal coaching agreements (Brunning, 2006; Kilburg \& Diedrich, 2007; McKenna \& Davis, 2009; Orenstein, 2007).

Of the five demands on leadership that McCall (2010) mentions, leadership coaching does not focus directly on tasks but on the people aspects of learning, growth and change in the self and colleagues (Nohria \& Khurana, 2010). Therefore, the goal of leadership coaching is to have a significant effect on the leadership abilities of employees (on the intrapersonal level) and on the leaders' relationships with colleagues (on the interpersonal level) in teams and in organisations (Lowman, 2002; Sperry, 2004).

The researcher chose positive psychology as the psychological perspective for this study because of its descriptive, philosophical and value resemblance to leadership (Peltier, 2001; Sheldon \& King, 2001). Positive psychology is the scientific study of strengths, virtues, positive emotions, traits and values intended to enable employees, organisations and 
communities to thrive (Linley \& Joseph, 2004; Seligman \& Csiksztmihalyi, 2000).

The literature (Linley \& Joseph, 2004; Peterson \& Seligman, 2004; Snyder \& Lopez, 2009) describes the primary task of positive psychology leadership coaching as identifying, applying and optimising individual strengths. Identifying is selecting the relevant constructs whilst applying is designing the coaching programmes and organising the actual coaching sessions with leaders.

The broad criteria for effective leadership guided the selection of the relevant constructs for inclusion in the Positive Psychology Leadership Coaching Programme (Lowman, 2002; Meyer \& Boninelli, 2007; Nohria \& Khurana, 2010). These were to improve self-awareness, internal motivation and effective interpersonal connections.

The researcher scrutinised the large variety of positive psychology constructs (Snyder \& Lopez, 2009; Lopez \& Lyubomirsky, 2008). They resulted in the list that follows:

- the leadership role links theoretically to engagement (Campbell \& Groenbaek, 2006)

- the many dimensions of engagement, sense of coherence and internal locus of control serve self-awareness (cognitive, affective and motivational); see Strümpfer, 1990; 1995 and 2005.

These emotional aspects do not include regulation and control. Therefore, the researcher included learned resourcefulness (Rosenbaum, 1990). Maslow and Rogers link effective interpersonal connections, as leadership characteristics, to self-actualisation (Cilliers \& Wissing, 1993). These constructs link to Biswas-Diener and Dean's (2007) descriptions of personal and social strengths. Their descriptions follow.

Work engagement (WENG) is a positive, fulfilling, workrelated, persistent and pervasive affective-cognitive state of mind that does not focus on any particular job, event, person or behaviour (Rothmann, 2002; Schaufeli \& Bakker, 2004; Simpson, 2009). WENG consists of three dimensions:

1. vigour, which is a high level of energy and mental resilience whilst working, a willingness to invest effort in one's work, not becoming fatigued easily and being persistent even in the face of difficulties

2. dedication, which is a strong involvement in one's work, being enthusiastic and proud of one's job and feeling inspired and challenged by it

3. absorption, which is being fully concentrated on one's work, a pleasant state in which one is totally immersed in one's work and forgets about everything else.

Learned resourcefulness (LR) is an acquired repertoire of complex cognitive behavioural skills that interact constantly with one's physical and social environment. When people are stressed (like when the smooth execution of a desired behaviour is threatened), they regulate and control their internal cognitive and emotional responses (Rosenbaum, 1990).
Sense of coherence (SOC) is a global orientation that expresses the extent to which one has a pervasive, enduring and dynamic feeling of coherence (Antonovsky, 1979; 1987; 1993). SOC has three dimensions; they are:

1. comprehensibility, which is making sense of the stimuli that come from one's internal and external environment and experiencing these as structured, predictable and explicable

2. manageability, which is believing that there are resources to meet the demands these stimuli pose and coping with them

3. meaningfulness, which is believing that these demands are challenges worthy of investment and engagement as well as being able to identify them emotionally and to commit oneself to handling them.

Self-actualisation values (SAV) are natural and dynamic lifelong processes of growth (Maslow, 1954; 1971) towards becoming what one can become. People actualise all their talents and potential fully, clearly and selflessly, with full concentration and absorption, whilst remaining fully human (Rogers, 1973; 1982) and actual (Du Toit, Grobler \& Schenck, 1998; Goldstein, 1963; Plas, 1996; Shostrom, 1976; Snyder \& Lopez, 2009).

This conceptualisation is congruent with forming sensitive relationships, as Cilliers and Wissing (1993) describe. It uses the theoretical constructs that Allport, Fromm Rogers, Frankl and Perls developed.

SAV consists of many intra and interpersonal dimensions. The intrapersonal dimensions are:

- reactivity (being responsive to one's own feelings and needs)

- emotional spontaneity (being free to act spontaneously and being oneself)

- self-regard (positive affirmation of the self in terms of one's own worth or strength)

- self-acceptance (accepting the self despite weaknesses or shortcomings)

- inner-support (acting independently and autonomously and making decisions in terms of one's own motivation and internalised principles whilst transcending and integrating the two extremes of being self-directed and other-directed in an optimal balance)

- time competence (a purposeful and realistic orientation towards the present, perceiving past experiences and expectations of the future as part of a meaningful continuum)

- an existential awareness (being able to behave in accordance with the demands of the situation without rigidly adhering to principles).

The interpersonal dimensions are:

- accepting one's own anger and aggression as natural and voluntary

- the capacity for intimate contact (being able to develop meaningful and intimate relationships with others without unduly emphasising expectations and obligations). 
Internal locus of control (ILOC) is the extent to which one perceives that one has control over a situation (Rotter, 1966; Schepers, 1995). ILOC is feeling free, in control, empowered and masterful. It is being able to act in a participative and enterprising manner; to see a relationship between one's own behaviour and outcomes; and to use one's own initiative, skill and judgement to solve problems, achieve results and develop constructive relationships.

The researcher identified a second layer of relevant positive psychology constructs. He did not include it when he designed and applied the Positive Psychology Leadership Coaching Programme. However, he used it as a link to the literature when he discussed the findings of the study. The layer consists of:

- wellness (Ryan \& Deci, 2000; Wissing \& Van Eeden, 2002)

- autonomy and optimism (Peterson, 2000)

- hardiness and resilience (Maddi \& Khoshaba, 2005)

- psychological and character strengths (Peterson \& Seligman, 2004; Snyder \& Lopez, 2009)

- psychological strengths (Rothmann \& Van Rensburg, 2002)

- emotional intelligence (Bar-On, 2010; Goleman, 1995; Jonker, 2009)

- positive emotions (Frederickson, 2001)

- curiosity

- coping (Basson \& Rothmann, 2002) with difficult emotions (Kashdan, 2009)

- spiral dynamic leadership values (Beck \& Cowan, 2006) based on Maslow's self-actualisation theory, Goleman et al., (2008), and Rooke and Torbert's (2005) conceptualisations of leadership style.

The South African positive psychology literature shows a strong theoretical and empirical interconnectedness between most of these constructs (see Breed, Cilliers \& Visser, 2006; Cilliers, 2000; Cilliers \& Coetzee, 2003; Cilliers \& Coetzee, 2010; Jackson, 2004; Naudé \& Rothmann, 2006; Pretorius, 2007; Rothmann, 2002; Storm, 2002; Strümpfer, 1990; 1995; 2005; 2007; Strümpfer et al., 2010; Van Der Colff \& Rothmann, 2009; Van Zyl, Deacon \& Rothmann, 2010; Wissing \& Van Eeden, 1997; 2002).

Using these results, the researcher hypothesised a positive psychology leadership profile. It consisted of physical energy, intellectual understanding, emotional sensitivity, an internal locus of control and interpersonal skills that facilitate growth. This profile corresponds to the ability to form sensitive relationships that Cilliers and Wissing (1993) conceptualised and operationalised.

The literature emphasises that the unexpected complexities - because of the demands of transformation, conflict, chaos, competition, paradox and limited resources (Meyer \& Boninelli, 2007; Will \& Codrington, 2004) - complicate the people leadership role. This implies that one has to authorise the self in complex matrix systems; move between different types and styles of leadership; manage complex and diverse interpersonal relationships; and deal with a constantly changing organisational identity (Eagly \& Chin, 2010; Nohria \& Khurana, 2010).
Positive psychology studies (Jackson, 2004; Strümpfer, Eiselen, Meiring \& Phalatse, 2010; Van der Colff \& Rothmann, 2009) showed how these complex interpersonal demands act as stressors in leaders with symptoms of self doubt, feelings of incompetence, depleted emotional resources, a sense of depersonalisation, a weak sense of coherence and a lack of experienced support from organisations. Although the leadership fraternity generally accepts these, there is almost no research to show that coaches can assist leaders to cope with these demands.

The same symptoms seem to exist in the South African financial industry, which is expanding rapidly into European and other African countries and experiencing unknown cultural and ethical practices (Human, 2005). Cilliers and Coetzee (2010) showed how leaders in these South African organisations apply their traditional South African values of governance and control to their people leadership role. Consequently, they are generally accused of not listening to, caring for or understanding their colleagues, with their different frames of reference, and their direct reports.

The researcher formulated the research question as: how can the lack of people leadership awareness amongst leaders in a financial organisation be addressed successfully?

The purpose of this study was to describe the positive psychology leadership coaching experiences of leaders in a large financial organisation. The researcher presents the research design in detail in the next section. He then presents the findings by theme and discusses the findings.

\section{Research design \\ Research approach}

The researcher used qualitative, descriptive (Brewerton \& Millward, 2004; Camic, Rhodes \& Yardley, 2003) and participatory action research (Terre Blanche, Durrheim \& Painter, 2006). This implies that the researcher was interested in, and concerned about, socially relevant values and ethics without being intimidated by power or status.

The researcher was actively involved in the research. He questioned what was actually happening and explored it using continuous reflection. He then described the behaviour in the context of the theoretical framework.

The researcher chose hermeneutics as the research paradigm (Clarke \& Hoggett, 2009). Simple hermeneutics allows one to understand leaders' subjective and inter-subjective experiences during coaching and the meaning they ascribe to their experiences. Double hermeneutics allows one to interpret their experiences critically from a positive psychology perspective (Alvesson \& Skoldberg, 2010).

\section{Research strategy}

The researcher chose a small pre-identified group (Bryman \& Burgess, 1999) of leaders for a single case study (Babbie \& Mouton, 2001; Bassey, 1999). He did this to investigate 
empirically the phenomenon of leadership coaching in a real-life context (Myers, 1997) and to examine in detail the manifesting behaviours that involve several sources of information rich in the coaching context (Creswell, 2003).

This strategy was appropriate because time and place limited the research. The coaching programme was the case under study through observation and recorded self-reports (Hollway \& Jefferson, 2010).

The research assumption was that the experiences of leaders would facilitate awareness of the self and of the relationship between the self and others. They would also determine the organisation's future inputs in terms of leadership development.

Therefore, the case study is intrinsic (obtaining a better understanding of the particular case to serve the interests of the researcher and the organisation) and instrumental (to give feedback to managers about the level of optimal psychological functioning of leaders); see Denzin and Lincoln (2005).

\section{Research method}

\section{Research setting}

The researcher conducted the study in a South African financial organisation. He introduced a coaching programme, as part of a larger leadership development programme, to assist leaders who could advance to adjust to their roles that the organisation's strategy indicated. He operationalised and linked the desired leadership behaviours to specific positive psychology dimensions (see Table 1).

The researcher designed the positive psychology coaching programme as an unstructured experiential learning event using encounter group methodology (Rogers, 1982). Its primary task was to allow participants to explore their leadership roles by focusing on the positive psychology dimensions in Table 1.

The coach was to be a facilitator according to the personcentred, Rogerian style based on the core dimensions of respect, realness and empathy (Rogers, 1982). The facilitator started each session by stating that 'this is an opportunity for you to explore how you took up your leadership role in the last two weeks'. The coach would then join the participants' discussions by offering reflections on how the positive psychology dimensions manifest (Cilliers, 2000; 2004a).
The coach invited leaders with the potential to advance to a 30-minute group meeting where the coach explained the rationale and logistics of the coaching programme. The participants had one week to accept the coaching invitation.

The participants then received ten hours of individual leadership coaching, in one-hour sessions over ten weeks, in the offices of the participants during office hours. Halfway into the programme (about session five) the coach attended a weekly or monthly meeting that each participant chaired. The coach processed each participant's interpersonal behaviour during the meeting in the session that followed.

\section{Entrée and establishing the researcher's roles}

The company's organisational development (OD) division authorised the researcher, as an external consultant, to design, plan and present the coaching programme. Based on the desired leadership behaviours, the organisation's strategy and leadership ethos, he suggested that he base the programme on a positive psychology perspective and person-centred facilitation.

The author is a registered psychologist (with the Health Professions Council of South Africa). He has practical and research experience in positive psychology and training in leadership coaching, specifically in person-centred, Rogerian facilitation (www.centerfortheperson.org).

\section{Sampling}

Of the 26 leaders in Gauteng, who the organisational development division identified as having potential for advancement, 11 accepted the invitation to attend the leadership coaching.

The sample consisted of seven males and four females, five Black and six White people, between 24 and 41 years of age. They had financial roles and at least three-year tertiary education qualifications. When reflecting on this convenient sample (Henning et al., 2004), the researcher considered:

- his interest in, and curiosity about, how this group of diverse leaders would engage with the coaching task

- how he chose the sample as the only leaders in this organisation available for coaching at that time

- how managers authorised this group of leaders to understand the effects of coaching.

The researcher's prolonged coaching engagement with the leaders (three months), his persistent observations (10 hours

TABLE 1: Coaching focus linked to positive psychology dimensions.

\begin{tabular}{ll}
\hline Desired leadership behaviour & Positive psychology dimensions \\
\hline Work engagement with the role of leader & Vigour (WENG), dedication (WENG) and absorption (WENG) \\
$\begin{array}{l}\text { Understand moving from management to leadership cognitively } \\
\begin{array}{l}\text { Emotional sensitivity about the self, own needs, feelings and values as well as the } \\
\text { emotional demands of the role }\end{array}\end{array}$ & $\begin{array}{l}\text { Absorption (WENG), self-control (LR), self-regulation (LR) and comprehension (SOC) } \\
\text { competence (SAV), meaningfulness (SOC), emotional resourcefulness (LR), time } \\
\text { spontaneity (SAV) }\end{array}$ \\
$\begin{array}{l}\text { Self-authorisation } \\
\begin{array}{l}\text { Facilitative communication (SAV), feeling reactivity (SAV) and emotional } \\
\text { reports and colleagues }\end{array}\end{array}$ & $\begin{array}{l}\text { Manageability (SOC), inner directedness (SAV) and ILOC } \\
\text { respect, realness as well as empathy (SAV) }\end{array}$ \\
\hline
\end{tabular}

WENG, work engatent: LR, learned resourcefulness; SOC, sense of coherence; SAV, self-actualisation values; ILOC, internal locus of control. 
per participant), as well as the richness (Onwuegbuzie \& Leech, 2005) and volume of the data compensated for the relative small sample.

The sample met the criteria that the participants would help to develop substantive leadership coaching theory further (Terre Blanche et al., 2006).

One should also note that the data offered saturation (Denzin \& Lincoln, 2005) and internal generalisability (Maxwell, 1992). In addition, seeing that there is already a significant body of theoretical knowledge in the field of positive psychology coaching, the sample was sufficiently large to study the demarcated behavioural constructs and answer the research question (Alvesson \& Sköldberg, 2010).

\section{Data collection methods}

The researcher used field notes (Mulhall, 2003) and participant essays (Camic et al., 2003). Therefore, the data contained the participants' reflections of their experiences and the coach's experiences of their behaviour. The advantage of using the two methods in combination was to integrate the coaching here-and-now contexts, processes and interactions (with colleagues) with the subjects' lived experiences (Mulhall, 2003).

The field notes contain the perceptions of the author mostly and are comprehensible only to him. The researcher's attention to detail whilst recording the raw data compensated for this (Denzin, 1989).

\section{Recording the data}

During and after each coaching session, the coach made field notes of the positive psychology dimensions, in the leadership context, as they manifested. After the last session, the coach asked each participant to write an essay (Van Manen, 1990; Wolcott, 2001) of about five A4 pages on: 'how did you take up your leadership role at the start of, during and towards the end of the coaching programme?' Therefore, the data was an individual and collective integration of the field notes and essays.

\section{Data analyses}

The researcher used discourse analysis (Breverton \& Millward, 2004; Camic, Rhodes \& Yardley, 2003; De Vos, Strydom, Fouché \& Delport, 2002; Henning, Van Rensburg \& Smit, 2004; LeCompte, Millroy \& Preissle, 1992).

Its purpose was to analyse participants' discussions about their experiences of the coaching. The process of interpretation followed the guidelines of Alvesson and Sköldberg (2010), Camic, Rhodes and Yardley (2003) and Terre Blanche et al. (2006): immersion and crystallisation. More specifically, this entailed the sequence of familiarisation, inducing themes, categorising into meaning, generating and elaborating themes and patterns, interpretation and writing. The desired leadership behaviours formed the discourse themes.
The coach interpreted each theme according to the positive psychology dimensions that manifested. The author then drew on his theoretical knowledge and subjective capacity to make sense of how the constructs manifested and changed during the 10 weeks of coaching.

Sorting the data led to different working hypotheses. These are 'sorting (the data) in a variety of ways, resulting in a variety of interpretations' (Terre Blanche et al., 2006, p. 342) and integrating them into a statement that is true for the time being and possibly reassessing them continuously in the light of further evidence (Schafer, 2003). The researcher integrated the working hypotheses into a research hypothesis.

\section{Strategies used to ensure quality data}

The researcher ensured trustworthiness in the paragraphs that follow (by following the guidelines of Brewerton \& Millward 2004; Camic et al., 2003; De Vos, Strydom, Fouché \& Delport, 2002; Denzin, 1989; Denzin \& Lincoln, 2005; Terre Blanche et al., 2006).

The researcher's competence, and because he asked two independent psychologists (to whom the theoretical model was well known) to peer-review the data and findings, ensured credibility. They declared the research dependable and confirmed saturation.

Reliability and replicating the research is difficult to report on. Therefore, the researcher ensured dependability by presenting detailed findings to ensure that its richness emerged.

The study showed strong and believable validity in its psychological description. It revealed the complexities of the positive psychology constructs and the interaction between them.

The researcher ensured confirmability by reflecting on how the findings lead to the themes and research hypothesis.

The researcher ensured transferability by reflecting on the findings of similar studies that Biswas-Diener and Dean (2007), Kilburg and Diedrich (2007) and Stout Rostron (2009) reported.

The organisation gave permission to the coach to conduct the research and to use his coaching programme. This assured ethicality (Terre Blanche et al., 2006). In addition, all the participants completed consent forms that covered the boundaries of time, venue, voluntary participation, conduct and confidentiality.

\section{Reporting}

The researcher reported the research findings by referring to the coaching context and the participants' experiences by theme.

In the discussion, the researcher linked the findings to the positive psychology dimensions. They resulted in a working 
hypothesis for each dimension. A discussion on the effect of the coaching followed the different working hypotheses and research hypothesis. Finally, the researcher formulated conclusions and recommendations.

\section{Findings}

Six themes emerged. These were the coaching context, engagement in role, understanding role complexity, emotional self-awareness and demands, self-authorisation and inability to facilitate the growth of others.

\section{The coaching context}

The participants made many noteworthy comments about their experiences of the leadership coaching. This made it necessary to report it as the first theme.

The participants described the initial sessions as 'difficult', 'a weird and 'strange experience', 'like a continuous delving into myself', 'I could not understand where it was going' and 'we sort of talked all around the same stuff'. Participants needed to 'go around in circles' before they could 'start working deeper' to discover that 'coaching is an experience in self-discovery'. After some time it made more sense 'when you start to understand what it is about'.

They described the later sessions in sentences like 'I realise that my struggles with my colleagues were actually about myself' and 'how my interactions with them always came back to me and my leadership communication style'.

The participants described the coaching experience as, 'an intense way of learning about yourself', 'very rewarding', 'absolutely worthwhile', 'filled with learning that no one can teach you in a class room' and 'the greatest learning experience I have ever had'. For some it was the first time in their lives that they had the 'luxury of talking about myself only' to someone 'who is only focusing on me and my issues' and that it was 'something I have never experienced at work'.

They saw the coaching sessions as cognitively and emotionally challenging. They described them as, 'intensely thought provoking', 'allowing me to make connections between issues that gave me many aha-moments' and 'an emotional challenge out of my comfort zone'. A few participants even recommended that the coaching 'be made available to all the leaders in our organisation'.

These descriptions showed the effect the coaching had. The participants had to overcome their resistance and develop curiosity about their own behaviour (Kashdan, 2009). They became more open, less rigid (as an aspect of SAV) about, and more involved in (as part of dedication -WENG) what their leadership behaviour could reflect about themselves. Their ability to self-regulate (as part of LR) and their vigour (as part of WENG) increased. The data showed that coaching fulfilled their personal developmental needs (Biswas-Diener \& Dean, 2007; Lopez \& Lyubomirsky, 2008; Nohria \& Khurana, 2010).
Some participants reported that the coaching reduced their loneliness in the organisation (Cilliers, 2004b).

\section{Working hypothesis 1}

The positive psychology coaching approach allowed leaders to move from initial apprehension, to an engagement with their own particular emotional behaviour, to using their own experiences to self-regulate and to tap into their vigour in order to engage with challenging cognitive and emotional leadership behaviours in more flexible ways than before.

\section{Engagement in role}

The coaching sessions started with the participants describing their leadership roles clearly in terms of the task outcomes (their financial projects). They made few references to interpersonal aspects. One participant reported that 'we tend to treat people as numbers on financial statements'.

Participants described this tendency as, 'we like to do what we can and reject what we can' $t$ ' and 'I know I am not good with people and it is therefore easier to just pretend that they are numbers'. This often led to participants realising that their overindulgence in the technicalities of their work are manifestations of their fear of engaging with people.

One participant stated this as, 'I realised when I was promoted into a leadership position I should take care of people more - but I resist that so strongly - I am an introvert and do not want to work with people'. Another stated that she was prepared to resign from her leadership position because of the stress and fatigue caused by 'the people issues and difficulties. I decided to give this coaching thing a chance - if this was not going to help, I will surely get back to pure financial work'. Some participants spoke about their disappointment when they realised that leadership 'does not have a clear how-to-do-it file'. Their stated 'incompetence to address people issues' resulted in their avoiding difficult meetings and disciplinary situations. One participant verbalised this as, 'I get so tired of the difficulties of dealing with people that I lock myself in the office and just do admin - which I don't even like doing'.

For some participants a shift came about halfway through the coaching when they realised that they had internalised fear. One participant remarked that'I know I am my own worst enemy - I am actually fearful of the stuff in myself and now I make this their problem'. For others a form of objectification helped them to understand their fear. One participant verbalised it as, 'I know I can be effective if I can only take each situation as it comes and not make it about me and my incompetence'. Others deliberately started to use their energy 'to turn problems into possibilities' to connect by reaching out and showing interest in people.

The possibilities and the successes they reported in consecutive sessions intrigued them. They would start these sessions by reporting voluntarily on how 'I think I was successful' in interpersonal situations 'by staying cool'. Two participants reported that they were still 'struggling with how to get myself more enthusiastic about what other people think and $d o^{\prime}$. 
The researcher interpreted these comments as initial low levels of engagement with their leadership roles (Sternberg, 2007). Participants have split leadership into what comes naturally and what is difficult. As the coaching progressed, their behaviour showed significantly higher levels of mental resilience and effort (vigour, as part of WENG), involvement and enthusiasm (dedication, as part of WENG) and concentration on, and immersion in (absorption as part of WENG), their 'difficult people task' (Simpson, 2009). For most participants, it took at least four sessions to engage with their people leadership roles. Thereafter, their excitement became visible and audible.

\section{Working hypothesis 2}

Leaders split their leadership tasks into technical tasks, which they prefer and are competent in, and into matters that involve interpersonal connection, which exhausted them and led to feelings of incompetence. Coaching was a vehicle to process their feelings of fear and incompetence, which many realised they had internalised. Participants seemed to need time to access their vigour and to turn their energy to addressing issues they thought were beyond them.

\section{Understanding role complexity}

When they spoke about their job content, participants cited their key performance areas, what their performance contracts measure objectively and how they needed to manage themselves to reach their financial targets. Their evidence shows that they were performing their jobs successfully (based on the outcomes they achieve) and intelligence (based on their abstract reasoning and differentiation skills).

Upon deeper investigation, the participants realised that their comments referred to management and excluded the complexity of the interpersonal aspect of leadership (Zaleznik, 1992). Some participants even forgot that they were working together as a team to reach their goals. One participant remarked 'realising now how I make the work only about me, makes me feel quite guilty'.

Participants found comfort in their individual and cognitive framing of their tasks and, because they performed their tasks excellently, they excluded the complexity of the relationship part of leadership. When they explored this boundary, the participants discovered areas of leadership like 'maybe leadership is far more demanding than I thought' and 'leadership seems to be doing things through other people'. The here-andnow (as part of SAV) was a key concept the researcher used successfully to merge the task and people orientations for most participants. The next theme explores it.

The researcher interpreted these findings as evidence of their increased levels of comprehension and sense making, their experience of work as being structured, predictable and explicable (as part of SOC), their concentration and immersion (as part of WENG) as well as their self-control and self-regulation (as part of LR).

\section{Working hypothesis 3}

Highly intelligent and successful managers, who focus on the individual and task targets they must reach, are not automatically effective leaders of people. When they moved from management to leadership, the leaders realised that they were ineffective when dealing with the relatively more challenging complexities encapsulated in interpersonal connection, especially as it manifests in the here-and-now. They had not yet fully realised how complex these challenges are. They may need practical experience followed by more coaching later.

\section{Emotional self-awareness and demands}

The coach's initial field notes revealed the participants' reluctance to explore their needs and feelings. This manifested in their strong urge to rationalise and intellectualise. It was as if feelings were taboo and therefore not accessible to them. Some participants explained their discomfort about sharing their feelings because of a fear of 'what these feelings could do to me' and 'how my feelings could hurt other people'. Others simply declared that 'feelings are not important to $m e$ ' and 'this airyfairy stuff does not belong in this organisation'.

Over time participants started to show more willingness to look at feelings in the there-and-then. A willingness to discuss previous meetings with colleagues and clients is an example. Half way through the coaching there was evidence of 'something loosening up'. This manifested in 'an outpouring of feelings' for three participants. They started to explore real and increasingly deeper feelings in the here-andnow of the coaching session - albeit about previous events like meetings with colleagues.

The researcher saw this as evidence that participants started the coaching with low emotional resourcefulness, unaware of their own needs and feelings and reluctant to explore them in any way. It was almost as if some participants showed evidence of 'alexithymia' - a condition where people have no access to their feelings (Goleman, 1995).

Increased feeling reactivity and spontaneity (as part of SAV) characterised their movement towards sensitivity and awareness. A few participants even started (jokingly) to remind the coach regularly to 'please, ask me how that makes me feel'. This exploration was almost taking risks - one participant remembered this as, 'it felt as if I was standing on a tightrope and did not know whether to go forward or backward'. Over time all the participants (even those who resisted their feelings strongly at the start) expressed the toughness of the emotional challenge and, at the same time, how worthy their investment in its exploration had become (as part of meaningfulness in SOC).

The more the participants explored their needs and feelings in the here-and-now, which the researcher interpreted as increased time competence (as part of SAV), the more they reported that they experienced themselves differently. They started to speak more clearly and strongly about who they 
really are and who they want to be as leaders. This was evidence of their self-regard and self-acceptance (both parts of SAV).

In their essays, many participants stated that they experienced feelings that surprised them. Examples are apprehension and fear about leadership, frustration and anger at those who 'pushed me into a position that I was not ready for', disappointment about 'not taking up the many and varied opportunities in the organisation' and hurt about being too strict on the self, colleagues and even family members. Some reflected on the necessity to process these feelings in order to understand the self and to move towards feelings that were more positive (Fredrickson, 2001). On the other hand, they experienced new insights into their happiness in life in general, pride about their accomplishments in their leadership positions and enthusiasm about their futures in the organisation (Lyubomirsky, 2001).

The researcher interpreted these experiences as manifestations of dedication (as part of WENG). A few participants could make connections between their levels of inspiration and transformational leadership (Nohria \& Khurana, 2010).

\section{Working hypothesis 4}

Hard work helped the leaders to move from a lack of emotional awareness to a level of emotional resourcefulness that a different sense of self, awareness of self and selfacceptance in the here-and-now characterised.

\section{Self-authorisation}

The participants described coaching as a journey from being focused outwards on tasks to becoming aware of themselves as, 'the principle decision maker and feeler' in their lives. They started by 'constantly blaming the organisation, management and my colleagues - even the client' for what was wrong. One participant remarked that 'I was always caught up in arguments about who is right or wrong', as if 'someone needs to be prosecuted' and 'it felt like constantly being involved in a court case'. During and after the coaching they reported starting to realise that they can 'work from within' and 'empower myself to help others'.

Participants said that the organisation had authorised them by appointing them as leaders and by selecting them for the coaching programme. On the other hand, their self-authorisation was problematic. Their strong focus on rationality and task made it difficult to access their emotional energy and awareness about interpersonal connections and authorising others: 'It took hard work to look within and see the potential inside to make my own decisions' and to 'use my inner energy to help my colleagues'.

The interpretation the researcher gave these findings was that the participants functioned with an external locus of control, disconnected, de-authorised and non-authentic (Linley \& Joseph, 2004). They learned to remind themselves constantly about the locus of their beings and to use inner directedness and support (as part of SAV) to achieve motivational independence. They also realised how many internal resources they had as forms of resilience (Masten, 2001) and how to manage this energy constantly (as part of SOC).

\section{Working hypothesis 5}

By constantly reminding themselves about their internal locus of control, the leaders moved from being disconnected from their inner needs and feelings to self-authorisation, which tapping into their own motivation, internalising principles and developing the ability to transcend and integrate the extremes of being self-directed and otherdirected characterised.

\section{Inability to facilitate the growth of others}

The participants managed their meetings in a content-driven and instructional manner. Initially, they were proud of 'the transactional way' in which they 'worked the agenda' and 'forced everyone to agree'. They even felt good and were happy in the team. They were 'good content decision makers' and 'enforcers of decisions'. One participant said 'I get along well with everyoneI don't ask them about their personal issues and feelings, and they are not interested in mine'. There was a sense of self-protection and they had an underlying fear that an emotional connection would lead to pressure to divulge very personal information that might lead to embarrassment and shame.

When the participants reflected on their interactions with colleagues, they started to see their 'autocratic' and 'telling' leadership styles that left little space for emotional connection or awareness of the processes of growth. The participants also reflected on the 'many missed cues' and 'lost opportunities' to make 'emotional contact' on 'issues that we constantly differ $o n$ '. Others reflected that 'maybe if I attended to how angry he was, he would not have stormed out of the room' and 'I think I could have made the climate in the room much more positive' if 'I only saw what was happening on the process level'.

As the coaching progressed, some participants reported on how they learned to differentiate between making an affective connection with a colleague in the here-and-now 'with no strings attached', improving the quality of the relationship and 'sharing deep personal feelings as one would experience in therapy'. It was as if participants needed to start trusting themselves with their own feelings to a point of acceptance before they could reach out to a colleague about some emotional issue (Cilliers, 1996).

Participants gave examples of how they later approached their colleagues with expressions like 'what are your feelings towards the new remuneration system' and 'how do you feel towards our top management'. One participant even started asking about 'your experience of me as a leader in this project'. He was very anxious and did not know what to do with the feedback he received.

The researcher interpreted these findings as evidence of increased intrapersonal awareness, of feelings in meetings 
and the effect of attending to these (as part of SAV). The participants reported that they were becoming sensitised to the feelings of others and the emotional effect this had on them afterwards.

After the coaching, participants were able to express their interpersonal feelings - even difficult feelings like anger and hurt (as part of SAV). The researcher interpreted this as a movement towards realness (a Rogerian core dimension); see Cilliers (2004a).

On the other hand, their interpersonal awareness and facilitating skills did not develop in the same way. They were not able to express their real feelings in the here-andnow, nor could they reflect on other people's experiences (as a micro skill); see Carkhuff (2000).

Therefore, the participants showed little realness and empathy in their interpersonal relationships as Rogerian core dimensions (1982). The researcher interpreted this fear (almost of a therapeutic outpouring) as an indication of how they had suppressed their own feelings over time and of how these may have to be processed before they would be able to attend to the feelings of others.

\section{Working hypothesis 6}

The coaching allowed the leaders to become aware of the roles that feelings play in their official interactions with colleagues and how they themselves respond emotionally. The programme did not facilitate the leaders' awareness of process or their ability to verbalise their emotional experiences in an interaction. They also could not reflect on colleagues using Rogerian core dimensions.

\section{Discussion}

The purpose of this study was to describe the positive psychology leadership coaching experiences of leaders in a large financial organisation. The importance of the study relates to a qualitative understanding of how leaders experience their roles differently when exposed to positive psychology feedback during coaching.

The researcher integrated the six working hypotheses into the research hypothesis that follows.

Positive psychology leadership coaching, as theoretically framed and experientially developed in this study, facilitates leaders' intrapersonal development. Its characteristics are:

- engagement with their roles

- increased cognitive understanding of the complexity of their roles

- increased emotional sensitivity towards the self, own feelings and needs

- a greater sense of self-authorisation

- a better awareness of how feelings and emotional experiences affect leadership activities.
The leaders did not show a noticeable improvement in their interpersonal ability to engage in discussions with colleagues to facilitate growth.

The researcher discussed the findings about the second layer of positive psychology constructs, namely, (1) wellness, (2) autonomy, (3) optimism, (4) hardiness, (5) resilience, (6) psychological and character strengths, (7) emotional intelligence, (8) positive emotions, (9) curiosity, (10) coping with difficult emotions, (11) spiral dynamic leadership values and (12) leadership style.

With regard to wellness, which Ryan and Deci (2000) conceptualised, the leaders were able to include autonomous behaviours and as optimism (Peterson, 2000) in their roles as leaders. This implied that their self-determination, intrinsic motivation and social development increased.

The findings suggested that shifts in the leader's hardiness and resilience occurred. With regard to denying the importance of feelings in leadership and avoiding one's own and others' emotional experiences, the leaders started to develop the resilience one needs to stay with difficult experiences and feelings for longer periods. According to Maddi and Khoshaba (2005), this resilience is based on hardiness. Hardiness refers to patterns of attitudes to cope with stressful situations and to turn distress into 'eustress' (growth-stimulating stress), followed by the courage and motivation to use the hardi-skills (resilience) of coping, social support and self-care as opposed to denial and avoidance.

The researcher found that the leaders could change their attitudes to higher levels of commitment, control and challenge and that their ability to cope moved towards higher levels of mental perceptiveness and understanding of decisive leadership.

Unfortunately, this was not true of their 'hardi-support' because the findings did not show evidence of emotional assistance to, and encouragement of, colleagues. Snook (2008) suggested that there is a relationship between individual hardiness (commitment, control and challenge), effectiveness of the organisation (cooperation, credibility and creativity) and transformational leadership. Therefore, one can interpret the leaders' organisational hardiness behaviour as a movement towards cooperation and credibility, but not towards creativity and the inspirational aspects of transformational leadership.

With regard to psychological and character strengths (Snyder \& Lopez, 2009), the findings suggested that the leaders became more willing to learn about and investigate their own emotional experiences. This illustrated their mindfulness and curiosity (Kashdan, 2009).

Their intrapersonal strengths (Biswas-Diener \& Dean, 2007) improved in terms of time orientation as they began to focus on the here-and-now (Shostrom, 1976) and became optimistic. On the other hand, their compassion (as part of empathy) did not develop during the coaching programme. 
The coaching programme stimulated their social strengths (Biswas-Diener \& Dean, 2007). Their courage, in becoming aware of others and, to some extent, in building relationships improved. Some leaders referred to their strengths of humanity (love and kindness). However, these strengths may have been part of their repertoires before the coaching began. The leaders did not reveal community-building strengths. The researcher learned this from their emotional inhibitions during meetings.

With regard to the many positive psychology constructs that focus on emotions, like emotional intelligence (Goleman, 1995), emotional differentiation and positive emotions (Fredrickson, 2001), emotional risk and coping with difficult emotions (Kashdan, 2009), the findings suggested the following.

The leaders learned to experience and describe so-called positive emotions like excitement, joy and happiness (mostly intrapersonal experiences). However, they struggled to acknowledge difficult feelings like guilt, shame and envy, let alone experience or understand their effects on leadership (mostly interpersonal experiences). Jonker (2009) reported on the success of an emotional intelligence development programme for accountants that concentrated on intra and interpersonal growth, which the emotional intelligence instruments (Bar-On-EQi and qualitative diary analysis) measure. The present research on leaders in the financial industry confirmed the intrapersonal but not the interpersonal growth.

Contrary to the popular view that positive psychology should not concern itself with difficult and negative feelings (Cilliers \& May, 2010), the findings suggested that, whilst leaders could move towards some acknowledgement of these feelings, they experienced relief, insight and connection with themselves and the coach (Cilliers \& Terblanche, 2010).

With regard to the spiral dynamics leadership values (Beck \& Cowan, 2006; Cowan \& Todorovic, 2010), the findings confirmed a strong focus on the task and governance (blue) values amongst the leaders at the start of the coaching. They preferred rules, structures, procedure, routines, order and traditional governance. They saw leadership as rewarding duty and punishing failure - as if all in the system were fulfilling their roles without choice. They managed by using positional power in an authoritarian and moralistic manner, communicated along the chain of command and believed in absolute truth and conduct.

The researcher interpreted this as an orientation towards power, an avoidance of the feeling components of leadership and an inclination to manage people as financial tasks. It was as if they transferred their 'shop floor metaphor' (of balancing books and driving projects) onto their leadership and used simplification as a defence against the complexity of managing people. They rejected the (red) values that represent the use of power and fighting leadership. This showed that they were not accessing their potential for power. This may explain their need 'to be empowered' and 'to empower my team'.
The coaching improved their awareness of values outside of their 'comfort zones'. This was evident when participants started to refer spontaneously to what their colleagues were thinking and feeling (the green value system) and when some of them started to integrate opposites in themselves (the yellow value system); see Beck and Cowan (2006). Towards the end of the coaching programme, many leaders mentioned their thinking or feeling conflict, which they started to see as a leadership paradox, and began to realise that integrating it is a life-long journey.

With regard to leadership style, the findings suggested the following.

According to the conceptualisation that Rooke and Torbert (2005) offer, the leaders initially functioned using the expert style: managing through logic, expertise and rational efficiency. As a group, the leaders moved towards the achiever style. Its characteristics are that one learns that one achieves goals through teams and that one can manage the expectations and behaviours of followers.

Some leaders did show characteristics of the strategist style as they became aware of how personal needs and the needs of the organisation meet in mutual inquiry, vigilance and vulnerability. The researcher found no evidence of the alchemist leadership style.

According to the conceptualisation of Goleman, Boyatzis and Mckee (2008), the leaders initially functioned in the coercive (dominant), authoritative (directive and goal-driven) and pacesetting (high standards of performance, number-driven, micromanagement and non-empathetic) styles.

As a group, the leaders moved towards the affiliative (increased awareness of people, bonding, alliances and creating harmony) and the democratic (influencing, appreciation of others' contributions and commitment) styles.

The researcher found little evidence of active listening skills, encouragement and linkages between individual needs and the needs of the organisation that the coaching leadership style expects.

When the researcher linked these behaviours to emotional intelligence (Goleman et al., 2008), he found that the leaders moved from being commanding (denying feelings through excessive directing) towards being more intra-personally authentic.

\section{Conclusions}

The researcher concluded that the leadership coaching programme:

- improved the leaders' intrapersonal awareness

- made the leaders more aware of their own needs and feelings 
- improved the leaders' ability to express their needs and feelings more openly than before

- offered the leaders space to think about and process their own emotional experiences and those of their colleagues

- improved the leaders' awareness of their feelings about others, the organisation and leadership as a concept

- improved the leaders' awareness of their leadership role in terms of its intellectual, emotional and motivational complexity

- improved the leaders' awareness of their own experiences

- did not equip the leaders sufficiently to enter relationships with colleagues in order to facilitate growth.

\section{Recommendations}

The researcher recommended that:

- all levels of leaders in the organisation should discuss the findings to assess the future possibilities for coaching

- the organisation should use the findings as a qualitative diagnosis of the skill levels of leaders

- the organisation should amend the leadership coaching programme to allow for more interpersonal exploration and skill building.

The researcher suggested facilitated discussions and roleplays on attending and responding skills (Carkhuff, 2000; Egan, 1975) as feedback on psychometric methodology.

Positive psychology practitioners should realise that just improving leaders' functioning on the various positive psychology constructs may not be enough to ensure effective leadership. Leaders who are unable to establish meaningful connections with colleagues that facilitate growth are ineffective.

\section{Limitations of the research}

The design and method limited this research. The researcher could have checked the choice of the constructs he included with colleagues and researchers in the field to ensure greater representivity. The coaching contract may have been too short to realise the desired levels of interpersonal learning and skills.

It is possible that talk coaching is not enough to build appropriate interpersonal skills. One person was in charge of the coaching and the researching. His subjectivity and bias could have influenced the data and the findings negatively.

The researcher suggested that future positive psychology leadership coaching research should focus on conceptualising and operationalising constructs that are specific to leadership. It should explore and explicate the link between the positive psychology constructs and the interpersonal complexities of leadership especially.

Maybe when coaches observe leaders in their natural environments for long periods, they could study more of their in vivo behaviour (as this researcher tried to do in the meetings in this study); see Hinshelwood and Skogstad (2005).

\section{References}

Alvesson, M., \& Sköldberg, K. (2010). Reflexive methodology. New vistas for qualitative research. Los Angeles, CA: Sage.

Antonovsky, A. (1993). The structure and properties of the sense of coherence scale. Social Science and Medicine, 36(6), 725-733. http://dx.doi.org/10.1016/02779536(93)90033-Z

Antonovsky, A. (1987). Unraveling the mystery of health: How people manage stress and stay well. San Francisco, CA: Jossey-Bass.

Antonovsky, A. (1979). Health, stress and coping. San Francisco, CA: Jossey-Bass.

Avolio, B. (2007). Promoting more integrative strategies for leadership theory building. American Psychologist, 62(1), 25-33. http://dx.doi.org/10.1037/0003066X.62.1.25, PMid:17209677

Azar, B. (2011). Positive psychology advances, with growing pains. Monitor on Psychology, 42(4), 32-36.

Babbie, E., \& Mouton, J. (2001). The practice of social research. Cape Town: Oxford University Press.

Bar-On, R. (2010). Emotional intelligence: An integral part of positive psychology. South African Journal of Psychology, 40(1), 54-62.

Bassey, M. (1999). Case study research in educational settings. Buckingham, UK: Open University Press.

Basson, M.J., \& Rothmann, S. (2002). Sense of coherence, coping and burnout of pharmacists. South African Journal of Economic and Management Sciences, 5(1), 35-62.

Beck, D.E., \& Cowan, C.C. (2006). Spiral Dynamics: Mastering Values, Leadership and Change. Oxford, UK: Blackwell Publishers.

Bennis, W. (2007). The challenges of leadership in the modern world. American Psychologist, 62(1), 2-5. http://dx.doi.org/10.1037/0003-066X.62.1.2, PMid:17209674

Biswas-Diener, R. (2010). Practicing positive psychology coaching: Assessment and strategies for success. Hoboken, NJ: Wiley.

Biswas-Diener, R., \& Dean, B. (2007). Positive psychology coaching. Hoboken, NJ: John Wiley.

Blake, R.R., \& McCanse, A.A. (1995). Leadership dilemmas - grid solutions. Houston, TX: Griff.

Breed, M., Cilliers, F., \& Visser, D. (2006). The factor structure of six salutogenic constructs. SA Journal of Industrial Psychology/SA Tydskrif vir Bedryfsielkunde, 32(1), 73-85.

Breverton, P., \& Millward, L. (2004). Organisational research methods. A guide for students and researchers. London, UK: Sage.

Brunning, H. (2006). Executive coaching. Systems-Psychodynamic perspective. London, UK: Karnac.

Bryman, A., \& Burgess, R.G. (1999). Qualitative research. Volume 1. London, UK: Sage. Buss, D.M. (2000). The evolution of happiness. American Psychologist, 55(1), 15-23. http://dx.doi.org/10.1037/0003-066X.55.1.15, PMid:11392858

Camic, P.M., Rhodes, J.E., \& Yardley, L. (2003). Qualitative research in Psychology. Washington, DC: APA.

Campbell, D., \& Groenbaek, M. (2006). Taking positions in the organisation. London, UK: Karnac.

Carkhuff, R.R. (2000). The art of helping. Amherst, MA: Human Resource Development Press.

Chapman, L., \& Cilliers, F. (2008). The integrated experiential executive coaching model: A qualitative exploration. South African Journal of Labour Relations, 32(1), 63-80.

Cherniss, C. (2010). Emotional intelligence: Towards clarification of a concept Industrial and Organisational Psychology, 3, 110-126. http://dx.doi.org/10.1111/ j.1754-9434.2010.01231.x

Cilliers, F. (1996). Facilitator training in South Africa. In R. Hutterer, G. Pawlowsky, P.F. Schmid, \& R. Stipsits (Eds.), Client Centred and Experiential Psychotherapy (pp. 547-555). Frankfurt am Main: Peter Lang.

Cilliers, F. (2004a). A Person-Centered view of diversity in South Africa. The Peson Centered Journal, 11(1-2), 33-47.

Cilliers, F. (2004b). Coaching. A systems Psychodynamic approach. HR Future, September, 41-42.

Cilliers, F. (2000). Facilitation skills for trainers. SA Journal of Industrial Psychology/SA Tydskrif vir Bedryfsielkunde, 26(3), 21-26.

Cilliers, F., \& Coetzee, M. (2010). Psychological profile of the young organisational leader: An explorative study. Manuscript submitted for publication.

Cilliers, F., \& Coetzee, S.C. (2003). The theoretical-empirical fit between three psychological wellness constructs: Sense of coherence, learned resourcefulness and self-actualisation. South African Journal of Labour Relations, 27(1), 4-24.

Cilliers, F., \& May, M. (2010). The popularisation of Positive Psychology as a defence against behavioural complexity in research and organisations. SA Journal of Industrial Psychology/SA Tydskrif vir Bedryfsielkunde, 36(2), Art. \#917, 10 pages. Industrial Psychology/SA Tydskrif vir Bedryfsi
http://dx.doi.org/10.4102/sajip.v36i2.917

Cilliers, F., \& Terblanche, L. (2010). The systems psychodynamic leadership coaching experiences of nursing managers. Health SA Gesondheid, 15(1), Art \#457, 9 pages. $\mathrm{http}: / / \mathrm{dx}$.doi.org/10.4102/hsag.v15i1.457 
Cilliers, F., \& Wissing M.P. (1993). Sensitive relationship forming as managerial dimension: The evaluation of a developmental programme. Journal for Industrial dimension: The evaluation
Psychology, 19(1), 5-10.

Clarke, S., \& Hoggett, P. (2009). Research beneath the surface. Psycho-Socail research methods in practice. London, UK: Karnac.

Coutu, D., \& Kaufman, C. (2009). What can coaches do for you? Harvard Business Review, January, 91-97.

Cowan, C., \& Todorovic, N. (2010). The never ending quest: Clare W Graves explores human nature. Retrieved November 07, 2010, from www.spiraldynamics.org

Creswell, J.W. (2003). Research design: Qualitative, quantitative and mixed methods. London, UK: Sage.

De Haan, E., \& Burger, Y. (2004). Coaching with colleagues - An action guide to one-toone learning. Basingstoke: Palgrave Macmillan.

De Vos, A.S., Strydom, H., Fouché, C.B., \& Delport, C.S.L. (2002). Research at grass roots. Pretoria: Van Schaik.

Denzin, N.K. (1989). Interpretive biography. London, UK: Sage.

Denzin, N.K., \& Lincoln, Y.S. (2005). The Sage handbook of qualitative research. London, UK: Sage.

Du Toit, A.S., Grobler, H.D., \& Schenck, C.J. (1998). Person-Centered communication. Johannesburg: International Thompson.

Eagly, A.H., \& Chin, J.C. (2010). Diversity and leadership in a changing world American Psychologist, 65(3), 216-224. http://dx.doi.org/10.1037/a0018957, PMid:20350020

Egan, G. (1975). The skilled helper. Monterey, CA: Brooks/Cole.

Evers, W.J.G., Brouwers, A., \& Tomic, W. (2006). A quasi-experimental study on management coaching effectiveness. Consulting Psychology Journal: Practice and Research, 58, 174-182. http://dx.doi.org/10.1037/1065-9293.58.3.174

Finn, F., Mason, C., \& Griffin, M. (2006). Investigating change over time - the effects of executive coaching on leaders' psychological states and behaviour. Paper presented at the 26th International Congress of Applied Psychology, 16-21 July 2001, Athens, Greece.

Fredrickson, B.L. (2001). The role of positive emotions in positive psychology. American Psychologist, 56(3), 218-226.

Goldsmith, M., Lyons, L., \& Freas, A. (2000). Coaching for leadership: How the world's greatest coaches help leaders learn. San Francisco, CA: Jossey-Bass.

Goleman, D. (1995). Emotional intelligence. New York, NY: Bantam.

Goleman, D., Boyatzis, R., \& McKee, A. (2008). The new leaders. Transforming the art of leadership into the science of results. London, UK: Sphere.

Goldstein, K. (1963). The organism. a holistic approach to biology derived from pathological data in man. Boston, MA: Beacon.

Grant, A.M. (2007). A languishing-flouring model of goal striving and mental health for coaching populations. International Coaching Psychology Review, 2(3), 250-264.

Grant, A.M. (2003). The impact of life coaching on goal attainment, metacognition and mental health. Social Behaviour and Personality, 31(3), 253-264. http://dx.doi. org/10.2224/sbp.2003.31.3.253

Greif, S. (2007). Advances in research on coaching outcomes. International Coaching Psychology Review, 2(3), 222-249.

Harvard Business Essentials. (2004). Coaching and mentoring. How to develop top talent and achieve stronger performance. Boston, MA: Harvard Business School.

Henning, E., Van Rensburg, W., \& Smit, B. (2004). Finding your way in qualitative research. Pretoria: Van Schaik.

Hinshelwood, R.D., \& Skogstad, W. (2005). Observing organisations. Anxiety, defence and culture in health care. London, UK: Routledge.

Hollway, W., \& Jefferson, T. (2010). Doing qualitative research differently. Los Angeles, CA: Sage.

Human, L. (2005). Diversity management for business success. Pretoria: Van Schaik.

Jackson, L.T.B. (2004). Burnout and engagement of teachers in the North West Province. Unpublished doctoral thesis. North-West University, Potchefstroom, South Africa.

Jonker, C.S. (2009). The effect of an emotional intelligence development programme on accountants. SA Journal of Human Resource Management/SA Tydskrif vir Menslikehulpbronbestuur, 7(1), Art. \#180, 9 pages. doi:10.4102/sajhrm.v7i1.183

Kaiser, R.B., Hogan, R., \& Craig, S.B. (2008). Leadership and the fate of organisations. American Psychologist, 63(2), 96-110. http://dx.doi.org/10.1037/0003066X.63.2.96, PMid:18284278

Kashdan, T. (2009). Curious? Discover the missing ingredient to a fulfilling life. New York, NY: William Morrow.

Kauffman, C. (2006). Positive psychology. The science at the heart of coaching. In D. Stober \& A.M. Grant (Eds.), Evidence based coaching handbook, (pp. 193-225). New York, NY: Wiley.

Kilburg, R., \& Diedrich, R. (2007). The wisdom of coaching: Essential papers in consulting psychology for a world of change. Washington, DC: American Psychological Association. http://dx.doi.org/10.1037/11570-000

LeCompte, M.D., Millroy, W.L., \& Preissle, J. (1992). The handbook of qualitative research in education. San Diego, CA: Academic Press.

Linley, P.A., \& Joseph, S. (2004). Positive psychology in practice. Hoboken, NJ: John Wiley.

Linley, P.A., Woolston, L., \& Biswas-Diener, R. (2009). Strengths coaching with leaders. International Coaching Psychology Review, 4(1).
Linley, P.A., \& Harrington, S. (2006). Strengths coaching: A potential-guided approach to aching psychology. International Coaching Psychology Review, 1(1), 37-46.

Lopez, S.J., \& Lyubomirsky, F.S. (2008). Positive psychology. Exploring the best in people. Westpoint, NY: Praeger.

Lowman, R.L. (2002). The handbook of organisational consulting Psychology. San Francisco, CA: Jossey-Bass.

Lyubomirsky, S. (2001). Why are some people happier than others? The role of cognitive and motivational processes in well-being. American Psychologist, 56(3) 239-249. http://dx.doi.org/10.1037/0003-066X.56.3.239, PMid:11315250

Maddi, S.R., \& Khoshaba, D.M. (2005). Resilience at work. How to succeed no matter what life throws at you. New York, NY: AMACOM.

Maslow, A.H. (1971). The farther reaches of human nature. New York, NY: Penguin.

Maslow, A.H. (1954). Motivation and personality. New York, NY: Harper \& Bros.

Masten, A.S. (2001). Ordinary magic: Resilience processes in development. American Psychologist, 56(3), 227-238. http://dx.doi.org/10.1037/0003-066X.56.3.227, PMid:11315249

Maxwell, J.A. (1992). Understanding and validity in qualitative research. Harvard Educational Review, 62, 279-299.

McCall, M.W. (2010). Recasting leadership development. Industrial \& Organisational Psychology, 3, 3-19.

McGovern, J., Lindemann, M., Vergara, M., Murphy, S., Barker, L., \& Warrenfeltz, R. (2001). Maximizing the impact of executive coaching. Behavioural change, organisational outcomes and return on investment. The Manchester Review, 6(1), $1-10$.

McKenna, D.D., \& Davis, S.L. (2009). Hidden in plain sight: The active ingredient of executive coaching. Industrial and Organisational Psychology, 2, 244-260. http:// dx.doi.org/10.1111/j.1754-9434.2009.01143.x

Meyer, T.N.A., \& Boninelli, I. (2007). Conversations in leadership. South African perspectives. Randburg: Knowres.

Mulhall, A. (2003). In the field: Notes on observation in qualitative research. Journal of Advanced Nursing, 41(3), 304-313. http://dx.doi.org/10.1046/j.13652648.2003.02514.x, PMid:12581118

Myers, M.D. (1997). Qualitative research in information systems. MIS Quarterly, 21(2), 241-242. http://dx.doi.org/10.2307/249422

Naudé, J.L.P., \& Rothmann, S. (2006). Work-related well-being of emergency workers in South Africa. South African Journal of Psychology, 36(1), 63-81.

Nelson, E., \& Hogan, R. (2009). Coaching on the dark side. International Coaching Psychology Review, 4(1), 7-17.

Nohria, N., \& Khurana, R. (2010). Handbook of leadership theory and practice. Boston, MA: Harvard Business Press.

Olivero, G., Bane, K.D., \& Kopelman, R.E. (1997). Executive coaching as a transfer of training tool: Effects on productivity in a public agency. Public Personnel Management, 26, 461-469.

Onwuegbuzie, A.J., \& Leech, N.L. (2005). The role of sampling in qualitative research. Academic Exchange Quarterly, Fall, 1-7.

Orenstein, R.L. (2007). Multidimensional executive coaching. New York, NY: Wiley.

Peltier, B. (2001). The psychology of executive coaching. Theory and application. New York, NY: Brunner-Routledge.

Peterson, C. (2000). The future of optimism. American Psychologist, 55(1), 44-55. http://dx.doi.org/10.1037/1061-4087.48.2.78

Peterson, C., \& Seligman, M.E.P. (2004). Character strengths and virtues: A handbook and classification. New York, NY: American Psychological Association.

Peterson, D.B. (1996). Executive coaching at work. The art of one-on-one change. Consulting Psychology Journal: Practice and Research, 48(2), 78-86. http://dx.doi. org/10.1037/1061-4087.48.2.78

Peterson, S.J., \& Luthans, F. (2003). The positive impact and development of hopeful leaders. Leadership and Development Journal, 24(1), 26-31. http://dx.doi. org/10.1108/01437730310457302

Plas, J.M. (1996). Person-Centered leadership. An American approach to participatory management. Thousand Oaks, CA: Sage.

Pretorius, L. (2007). Resilience, self-efficacy and burnout of employees in a chemical organisation. Unpublished master's dissertation, North-West University, Potchefstroom, South Africa.

Robson, D. (2011). Measuring value in the coaching relationship. Strategic HR Review, 10(1).

Rogers, C.R. (1982). Freedom to learn for the 80s. Columbus, OH: Charles E. Merrill.

Rogers, C.R. (1973). Client-centered therapy. London, UK: Constable.

Rooke,D., \& Torbert, W.R. (2005). Seven transformations of leadership. Harvard Business Review, April, 1-11.

Rosenbaum, M. (Ed.). (1990). Learned resourcefulness: On coping skills, self-control and adaptive behaviour. New York, NY: Springer.

Rothmann, S. (2002). Burnout and engagement: a fortigenic perspective. Inaugural lecture, Potchefstroom University, Potchefstroom.

Rothmann, S., \& Van Rensburg, P. (2002). Psychological strengths, coping and suicide ideation in the South African Police Services in the North West province. SA Journal of Industrial Psychology/SA Tydskrif vir Bedryfsielkunde, 28(3), 39-49.

Rotter, J. (1966). Generalized expectations for internal versus external control of reinforcements. Psychological monographs: General and applied, 80(1), 1-28. 
Ryan, R.M., \& Deci, E.L. (2000). Self-determination theory and the facilitation of intrinsic motivation social development and well-being. American Psychologist, 55(1), 68-78. http://dx.doi.org/10.1037/0003-066X.55.1.68, PMid:11392867

Schafer, R. (2003). Insight and interpretation. The essential tools of psychoanalysis. London, UK: Karnac.

Schaufeli, W.B., \& Bakker, A.B. (2004). Job demands, job resources and their relationship with burnout and engagement: A multi-sample study. Journal of Organisational Behavior, 25, 1-23. http://dx.doi.org/10.1002/job.248

Schepers, J.M. (1995). Die lokus van beheer vraelys: Konstruksie en evaluering van 'n meetinstrument [The locus of control questionnaire: Construction and evaluation of a measuring instrument]. Johannesburg: RAU.

Seligman, M.E.P., \& Csikszentmihalyi, M. (2000). Positive psychology. An introduction American Psychologist, 55(1), 5-14. http://dx.doi.org/10.1037/0003-066X.55.1.5 PMid:11392865

Seligman, M.E.P., Steen, T.A., Park, N., \& Peterson, C. (2005) Positive psychology progress. Empirical validation of interventions. American Psychologist, 60(5), progress. Empirical validation of interventions. American Psychologist,
410-421. http://dx.doi.org/10.1037/0003-066X.60.5.410, PMid:16045394

Sheldon, K.M., Kashdan, T.B., \& Steger, M.F. (2011). Designing the future of positive psychology. Oxford: Oxford University Press. http://dx.doi.org/10.1093/acprof:0 so/9780195373585.001.0001

Sheldon, K.M., \& King, L. (2001). Why positive psychology is necessary. American Psychologist, 56(3), 216-217. http://dx.doi.org/10.1037/0003-066X.56.3.216, PMid:11315247

Shostrom, E.L. (1976). Actualizing Therapy. Foundations for a Scientific Ethic. San Diego, CA: Edits.

Simpson, M.R. (2009). Engagement at work: A review of the literature. Internationa Journal of NursingStudies, 46, 1012-1024. http://dx.doi.org/10.1016/j. ijnurstu.2008.05.003, PMid:18701104

Snook, S.A. (2008). Love and fear and the modern boss. Harvard Business Review, $86(1)$.

Snyder, C.R., \& Lopez, S.J. (2009). Oxford handbook of positive psychology. New York, NY: Oxford University Press.

Sperry, L. (2004). Executive coaching. The essential guide for mental health professionals. New York, NY: Brunner-Routledge.

Sternberg, R.J. (2007). A systems model of leadership: WICS. American Psychologist, 62(1), 34-42. http://dx.doi.org/10.1037/0003-066X.62.1.34, PMid:17209678

Storm, K. (2002). Burnout and work engagement of teachers in the South African Police Services. Unpublished doctoral thesis, Potchefstroom University, Potchefstroom, South Africa.
Stout Rostron, S. (2009). Business coaching. Wisdom and practice. Unlocking the secrets of business coaching. Randburg: Knowledge Resources.

Strümpfer, D.J.W. (2007). Lest we forget that Industrial and organisational psychology is psychology. SA Journal of Industrial Psychology/SA Tydskrif vir Bedryfsielkunde, 33(1), 1-7.

Strümpfer, D.J.W. (2005). Standing on the shoulders of giants: Notes on early positive psychology (Psychofortology). South African Journal of Psychology, 35(1), 21-45.

Strümpfer, D.J.W. (1995). The origins of health and strength: From 'salutogenesis' to 'fortigenesis'. South African Journal of Psychology, 25(2), 81-89.

Strümpfer, D.J.W. (1990). Salutogenesis: A new paradigm. South African Journal of Psychology, 20(4), 265-276.

Strümpfer, D.J.W., Eiselen, R.J., Meiring, D., \& Phalatse, J.S. (2010). Validating measures of psychological well-being by contrasting samples employees in hazardous and less hazardous work. Journal of Psychology in Africa, 20(1), 23-32.

Terre Blanche, M., Durrheim, K., \& Painter, D. (2006). Research in practice. Applied methods for the social sciences. Cape Town: UCT Press.

Van Der Colff, J.J., \& Rothmann, S. (2009). Occupational stress, sense of coherence, coping, burnout and work engagement of registered nurses in South Africa. South African Journal of Industrial Psychology/SA Tydskrif vir Bedryfsielkunde, 35(1), Art. \#423, 10 pages.

Van Manen, M. (1990). Researching lived experience. Toronto, ON: State University of New York.

Van Zyl, L.E., Deacon, E., \& Rothmann, S. (2010). Towards happiness: Experiences of work-role fit, meaningfulness and engagement of industrial/organisational psychologists in South Africa. South African Journal of Industrial Psychology/SA Tydskrif vir Bedryfsielkunde, 36(1), Art \#890, 10 pages. http://dx.doi.org/10.4102/ sajip.v36i1.890

Wall, B. (2007). Coaching for emotional intelligence. New York, NY: Amacom.

Will, B., \& Codrington, G. (2004). Coaching: Perspectives on leadership. Management Today, 20(7), 51-53.

Wissing, M.P., \& Van Eeden, E. (2002). Empirical clarification of the nature of psychological well-being. South African Journal of Psychology, 32(1), 32-44.

Wissing, M.P., \& Van Eeden, C. (1997). Psychological well-being: A fortigenic conceptualization and empirical clarification. In The 3rd Annual Congress of the Psychological Society of South Africa, $10-12$ September 1997. Durban: The Psychological Society of South Africa.

Wolcott, B.L. (2001). Writing up qualitative research. London, UK: Sage.

Zaleznik, A. (1995). Managers and leaders. Are they different? Harvard Business Review, 70(2), 1-11. 